\title{
PENGARUH PENGGUNAAN MODEL PEMBELAJARAN BERBASIS MASALAH TERHADAP HASIL BELAJAR QUR'AN HADITS
}

\author{
Muhammad Fahrurrozi \\ UIN Mataram \\ Email: fahrurrozi.ntb@gmail.com
}

\begin{abstract}
Abstrak: Penelitian ini bertujuan untuk mengetahui pengaruh model pembelajaran berbasis masalah terhadap hasil belajar Qur'an Hadits siswa Madrasah Tsanawiyah Nurul Islam Sekarbela. Penelitian ini merupakan penelitian eksperimen dengan menggunakan one grup pretest dan posttest design. Populasi dalam penelitian ini adalah seluruh siswa kelas VII Madrasah Tsanawiyah Nurul Islam Sekarbela tahun ajaran 2018/2019. Sampel ditentukan melalui tehnik random sampling Dengan Instrumen penelitian dalam bentuk tes essay. Analisis data penelitian dengan uji-t sampel berpasangan. Analisis uji hipotesis dalam penelitian ini menunjukkan signifikansi sebesar 0.003 lebih kecil daripada 0.05 artinya ada perbedaan signifikan hasil belajar antara siswa saat pretest dan posttest. Dengan demikian dapat disimpulkan, bahwa model pembelajaran berbasis masalah berpengaruh terhadap hasil belajar siswa di Madrasah Nurul Islam Sekarbela.
\end{abstract}

Kata kunci: model pembelajaran berbasis masalah, hasil belajar

Title: The Effect of Use Problem Based Learning Models on Learning Results of the Qur'an Hadits

Abstrak: The purpose of this study was determine the effect of problem-based learning models on the student learning outcomes in subjects of the Qur'an Hadith at the Madrasah Tsanawiyah Nurul Islam Sekarbela. This research is an experimental study using one group pretest and posttest design. The population in this study were students of class VII Madrasah Tsanawiyah Nurul Islam Sekarbela in the 2018/2019 school year. The sample is determined through a random sampling techniques. The research instrument is an essay test. Analysis of research data is paired sample t-test. Hypothesis test analysis shows that the t-test 0.003 is smaller than 0.05, meaning that there are significant differences in learning outcomes between students during the pre-test and post-test. Thus it can be concluded, that the problem-based learning model influences student learning outcomes in Madrasah Nurul Islam Sekarbela.

Keywords: problem-based learning model, learning outcome 


\section{PENDAHULUAN}

Saat ini pendidikan di Indonesia terus mengalami perkembangan, hal ini tampak dari perkembangan kurikulum nasional yang ada. Kurikulum terdiri dari unsur proses yang bersifat formal ataupun informal yang ditujukan bagi peserta didik untuk mendapatkan pengetahuan ataupun pemahaman, meningkatkan keahlian ataupun mengubah apresiasi tingkah laku serta nilai melalui bantuan yang diberikan oleh sekolah. ${ }^{1}$

Kurikulum yang digunakan mayoritas sekolah termasuk di madrasah pada tahun 2018 adalah kurikulum 2013. Kurikulum 2013 ialah suatu kurikulum yang disusun untuk menyediakan manusia Indonesia agar mempunyai keahlian hidup sebagai pribadi yang baik dan menjadi warga negara yang bertakwa, produktif, kreatif, inovatif dan afektif serta dapat berkontribusi dalam kehidupan bermasyarakat di indonesia, berbangsa, bernegara dan peradaban dunia. Kurikulum 2013 direvisi dari kurikulum 2006 (KTSP) yang didasari pemikiran tentang tantangan masa yang akan datang, pandangan masyarakat, peningkatan pengetahuan dan pedagogi, kompetensi masa depan, dan kejadian negatif yang mengemuka. ${ }^{2}$ Melalui kurikulum 2013 diharapkan pendidik dapat meningkatkan kemampuan peserta didik, baik dari aspek sikap, pengetahuan maupun keterampilan.

Salah satu aspek penting yang menjadi kunci keberhasilan pelaksanaan Kurikulum 2013 adalah kegiatan pembelajaran. Secara global pembelajaran dapat kita maknai sebagai suatu aktivitas yang dikerjakan secara sadar dan tersusun oleh guru sebaik mungkin, sehingga pengetahuan dan prilaku peserta didik dapat berubah ke jalan yang lebih baik dari sebelumnya. Menurut Gagne, Briggs dan Wager dalam Rusmono, pembelajaran merupakan sebuah uraian kegiatan yang dirancang agar dapat memungkinkan terjadinya proses belajar pada siswa (instruction is set of events that effect learners in such a way that learning is facilited). ${ }^{3}$ Sedangkan Smith dan Ragan (dalam Rusmono) mengartikan pembelajaran sebagai suatu aktifitas untuk menyampaikan informasi guna membantu siswa untuk meraih tujuannya, terlebih tujuan itu berbentuk tujuan belajar ataupun tujuan peserta didik dalam belajar. ${ }^{4} \mathrm{Jadi}$ pembelajaran adalah sebuah usaha untuk membuat situasi dan kondisi guna terciptanya sebuah proses belajar yang memungkinkan peserta didik mendapatkan pengalaman dalam proses belajar yang kondusif untuk mewujudkan tujuan siswa dalam belajar. ${ }^{5}$

\footnotetext{
1 Ali Mudlofir, Aplikasi Pengembangan Kurikulum Tingkat Satuan Pendidikan Dan Baban Ajar Dalam Pendidikan Agama Islam (Jakarta: PT. Raja Grafindo Persada, 2012), h. 1-2.

2 Permendikbud No. 69 Tahun 2013 Tentang Kerangka Dasar Dan Struktur Kurikulum Sekolah Menengah Atas/Madrasah Aliyah (Jakarta: Kemdikbud, 2013), h. 1.

${ }^{3}$ Rusmono, Strategi Pembelajaran dengan Problem Based Learning Itu Perlu (Jakarta: Ghalia Indonesia, 2012), h. 6 .

${ }^{4}$ Ibid., h.7.

${ }^{5}$ Gulsah Kulekci - Esin Kumlu, "Developing Critical Thinking Skills In English Language Teaching Classes Through Novels". International Journal of Language Academy, Vol. 3 No. 2, Summer 2015, h.76.
} 
Penciptaan suatu kondisi yang memungkinkan peserta didik untuk belajar tersebut dapat dilakukan oleh guru melalui penggunaan media pembelajaran maupun metode pembelajaran yang tepat. Ketepatan dalam pemilihan metode dan media pembelajaran ini tentunya secara langsung maupun tidak langsung akan berpengaruh terhadap tujuan-tujuan pembelajaran yang salah satunya tercermin melalui perolehan hasil belajar oleh peserta didik. Mc. Millan merumuskan bahwa hasil belajar adalah suatu hal yang diketahui dan dapat dilakukan oleh siswa sebagai akibat dari kegiatan pembelajaran. ${ }^{6}$ Sedangkan Rusmono mengartikan hasil belajar sebagai perubahan tinhkah laku seseorang yang menyangkut ranah kognitif, apektif ataupun psikomotor yang diperoleh melalui interaksi dengan berbagai sumber belajar dan lingkungan belajar. ${ }^{7}$ Jadi dapat dikatakan bahwa ketidaktepatan guru dalam menggunakan media maupun metode pembelajaran akan berpengaruh terhadap perolehan hasil belajar peserta didik.

Hal ini sejalan dengan hasil penelitian pendahuluan dan wawancara yang dilakukan di MTs. Nurul Islam Sekarbela dimana berdasarkan hasil analisis terhadap dokumen nilai ulangan harian kelas VII dan wawancara terhadap guru dan siswa diperoleh data awal yang menunjukkan bahwa hasil belajar PAI, khususnya mata pelajaran Qur'an Hadits, siswa kelas VII tahun ajaran 2018/2019 masih perlu ditingkatkan. Ada banyak model pembelajaran yang dapat dilakukan untuk dapat meningkatkan hasil belajar diantaranya model pembelajaran berbasis masalah (problem based-learning). Penelitian terdahulu menunjukkan bahwa model PBL efektif untuk meningkatkan hasil belajar. ${ }^{8}$ Untuk itu, artikel ini menguraikan efektifitas penggunaan model pembelajaran berbasis masalah (problem based-learning) terhasap hasil belajar siswa di madrasah tsanawiyah dalam setiaap tahapan/fase pembelajarannya pada mata pelajaran Qur'an Hadits.

${ }^{6}$ Mc. Millan, James H., Classroom Assessment, Principles \& Practice for Effective Standars-Based Instruction (Boston: Person Education Inc., 2007), h. 28.

${ }^{7}$ Rusmono, Strategi Pembelajaran, h. 10.

8 Ni Nyoman Sri Lestari, "Pengaruh Model Pembelajaran Berbasis Masalah (Problembased Learning) dan Motivasi Belajar terhadap Prestasi Belajar Fisika bagi Siswa Kelas VII SMP," Jurnal Teknologi Pembelajaran Indonesia 1, no. 2 (Oktober 2012), http://ejournal-pasca.undiksha.ac.id/index.php/jurnal_tp/article/view/297; I. Ketut Reta, "Pengaruh Model Pembelajaran Berbasis Masalah terhadap Keterampilan Berpikir Kritis Ditinjau dari Gaya Kognitif Siswa," Jurnal Pendidikan dan Pembelajaran IPA Indonesia 2, no. 1 (Januari 2012), http://ejournal-pasca.undiksha.ac.id/index.php/jurnal_ipa/article/view/403; Tomi Utomo, Dwi Wahyuni, dan Slamet Hariyadi, "Pengaruh Model Pembelajaran Berbasis Masalah (Problem Based Learning) terhadap Pemahaman Konsep dan Kemampuan Berpikir Kreatif Siswa (Siswa Kelas VIII Semester Gasal SMPN 1 Sumbermalang Kabupaten Situbondo Tahun Ajaran 2012/2013)," Jurnal Edukasi 1, no. 1 (Maret 2014): 5-9, https://jurnal.unej.ac.id/index.php/JEUJ/article/view/1025; Ahmad Syaifulloh, "Pengaruh Strategi ProblemBased Lear-Ning (PBL) terhadap Motivasi dan Hasil Belajar Peserta Didik pada Mata Pelajaran Fiqih di MA. Khozinatul 'Ulum Blora Jawa Tengah," Wahana Akademika: Jurnal Studi Islam dan Sosial 3, no. 2 (Desember 2016): 121-136, http://journal.walisongo.ac.id/index.php/wahana/article/view/1148. 


\section{METODE PENELITIAN}

Penelitian ini merupakan penelitian eksperimen dengan menggunakan desain one grup pretest dan posttest design. Dalam desain diambil satu kelompok sampel, selanjutnya diberi pretest dan posttest kemudian dilihat perbedaan antara nilai pretest dan posttest. ${ }^{9}$ Adapun rancangan eksperimen dalam penelitian ini ditunjukkan dalam di bawah ini:

\section{One Group Pretest-Posttest Design}

\begin{tabular}{clc}
\hline Pre test & Perlakuan (X) & Post test \\
\hline O1 & Model PBL & O2 \\
\hline
\end{tabular}

Keterangan :

O1 : Pre-test

O2 : Post-test

Pendekatan penelitian adalah salah satu aspek penting dalam berhasilnya penelitian yang akan dilaksanakan. Hal ini disebabkan karena pendekatan penelitian akan mempengaruhi cara peneliti untuk menjawab suatu permasalahan dari sebuah penelitian. Pendekatan yang digunakan pada penelitian ini adalah pendekatan kuantitatif. Pendekatan ini digunakan karena pemecahan masalah harus relevan dengan rumusan masalah yang membutuhkan perhitungan dan pengukuran terhadap variabel dan pengujian terhadap hipotesis yang telah ditentukan.

Pendekatan kuantitatif digunakan juga karena dalam penelitian ini menggunakan datadata numarik yang bisa dianalisis dengan menggunakan metode statistik. Pendekatan kuantitatif memiliki tujuan untuk menguji suatu teori yang menjelaskan tentang bagaimaan hubungan antara kenyataan sosial, pengujian ini memiliki tujuan untuk mengetahui apakah teori yang ditetapkan tadi sesuai dengan kenyataan ataupun bukti-bukti emperis atau tidak. ${ }^{10}$

Data-data numerik yang ada diperoleh dalam bentuk tes essay yang berjumlah 9 butir soal yang valid dan reliabel (sudah melalui tahap uji coba instrumen). Apabila benar semua maka total skor keseluruhan adalah 100 materi yang akan diujikan pada materi Quran Hadits yang diberikan saat pretest dan posttest, yang kemudian diuji menggunakan uji-t dengan alat bantu program SPSS for Windows 16.

\section{HASIL DAN PEMBAHASAN}

Data penelitian ini adalah dari hasil pretest dan posttest pada kelas eksperimen dengan model pembelajaran berbasis masalah. Data hasil belajar dijadikan dasar dalam uji hipotesis..

9 Sugiono, Metode Penelitian Pendidikan Pendekatan Kuantitatif, Kualitatif, dan R \&OD. (Alfabeta: Bandung. 2001), h. 64.

10 Ibnu Hadjar, Dasar-dasar Metodologi Penelitian Kwantitatif dalam Pendidikan, (Jakarta: PT Raja Grafindo Persada, 2001), h. 30. 
Rangkuman Uji-t Data Hasil Belajar Siswa

\begin{tabular}{ccccc}
\hline No. & Variabel & thitung & sig. & Keterangan \\
\hline 1. & Hasil Belajar & 4,2 & 0,003 & Ada perbedaan signifikan \\
\hline
\end{tabular}

Berdasarkan Tabel di atas nilai hasil belajar thitung sebesar 4,2 dengan signifikansi 0,003 dimana signifikansinya lebih kecil daripada 0,05 sehingga $\mathrm{H}_{\mathrm{o}}$ ditolak artinya ada perbedaan hasil belajar siswa yang signifikan siswa saat pretest dan posttest. Perbedaan tersebut menunjukkan adanya efektivitas penerapan model pembelajaran berbasis masalah terhadap peningkatan hasil belajar siswa.

Adanya perbedaan signifikan diatas karena adanya proses diskusi siswa dalam pembelajaran Qur'an Hadits kelas VII yang dilaksanakan guru di MTs. Nurul Islam Sekarbela didasarkan pada tahapan pembelajaran berbasis masalah yang dikembangkan Nur, dkk. yang menuntut siswa untuk aktif, adapun beberapa fase pembelajaran berbasis masalah yang dilaksanakan dalam penelitian ini antara lain:

Fase 1: Mengorientasikan Siswa untuk Merumuskan Masalah

Langkah mengorientasi siswa pada masalah ini dilaksanakan guru dengan memberikan pertanyaan-pertanyaan dan penugasan untuk memancing siswa mengungkapkan permasalahan-permasalahan yang terkait dengan kehidupan yang tenang berdasarkan prinsip kejujuran, amanah, dan istiqomah.

Fase 2: Membimbing siswa untuk mengemukakan ide-ide atau pemikiran untuk pemecahan masalah

Fase ini dilakukan guru dengan membentuk kelompok-kelompok siswa dimana masingmasing kelompok akan memecahkan masalah yang ada di dalam kelompoknya. Prinsipprinsip pengelompokan siswa dalam pembelajaran kooperatif dapat digunakan dalam konteks ini seperti: kelompok harus heterogen, pentingnya interaksi antar anggota, komunikasi yang efektif, adanya tutor sebaya, dan sebagainya.

Fase 3: Membantu penyelidikan mandiri dan kelompok

Pada fase ini, guru berusaha mendorong siswa untuk mengumpulkan data dan melaksanakan penyelidikan sampai mereka betul-betul memahami dimensi situasi permasalahan. Pada fase ini, selain melalui buku-buku sumber utama, penyelidikan untuk pemecahan masalah juga diarahkan guru melalui kegiatan kajian buku-buku sumber pendukung di perpustakaan dan internet, dalam hal ini adalah perpustakaan MTs. Nurul Islam Sekarbela.

Fase 4: Mengembangkan dan manyajikan hasil karya serta memperbandingkan dengan kelompok lain 
Tahap penyelidikan diikuti dengan menciptakan hasil karya dan memperbandingkannya. Sebagai langkah memamerkan hasil karya, siswa diarahkan untuk mempresentasikan hasilnya dan kelompok lainnya menjadi "penilai” atau memberikan umpan balik.

Fase 5: Analisis dan evaluasi proses pemecahan masalah

Selama fase ini guru berupaya merekonstruksi kembali pemikiran dan aktivitas siswa yang telah dilakukan selama proses kegiatan belajarnya. Bagaimana pemahaman siswa terhadap suatu masalah? Solusi apa yang dapat mereka berikan atas penyelesaian masalah tersebut? Apakah solusi tersebut cukup efektif menyelesaikan masalah tersebut? dan lainlain. $^{11}$

Setelah melalui proses pembelajaran berbasis masalah dengan langkah-langkah pembelajaran di atas menunjukkan adanya peningkatan hasil belajar siswa yang ditunjukkan dari perbandingan hasil belajar pada saat posttest lebih tinggi dibandingkan dengan saat pretest.

Perbedaan hasil belajar pada saat pretest dan posttest, disebabkan aktifnya siswa dalam pembelajaran hal ini sejalan dengan pendapat Warsono dan Hariyanto tentang karakteristik PBL yang menyatakan bahwa kelebihan dari PBL adalah: a) Membuat peserta didik terbiasa menghadapi suatu permasalahan baik permasalahan tadi terjadi di dalam kelas taupun di luar kelas, b) menanamkan rasa kepedulian terhadap hubungan sosial yang terjalin dengan masyarakat di sekelilingnya, c) menjalin interaksi yang harmonis antara guru dengan peserta didik, serta d) melatih peserta didik untuk mampu mengimplementasikan metode eksperimen melalui sebuah proses pemecahan masalah. ${ }^{12}$

Hal lain yang mendukung keberhasilan model pembelajaran berbasis masalah pada pembelajaran Qur'an Hadits pada kelas VII di MTs. Nurul Islam Sekarbela adalah bahwa pembelajaran siswa dibagi dalam kelompok-kelompok yang anggotanya heterogen. Dalam kerja kelompok siswa yang pandai mengajari yang lemah (baca: kurang/belum pandai), yang tahu memberitahu yang belum tahu, yang cepat menangkap mendorong temannya yang lambat, yang punya gagasan/ide segera memberikan usul. Layaknya suatu proses interaksi siswa maka dalam kelompok siswa juga harus bersedia berbicara dan berpendapat, mendengarkan pendapat orang lain, dan berkolaborasi membangun pengetahuan secara bersama (kelompok) lebih baik dibandingkan dengan belajar sendiri.

Semua kemampuan tersebut memang tidak terlepas dari pengetahuan awal yang dimiliki siswa. Sebagaimana diketahui bahwa hasil belajar yang dicapai siswa sebelum pembelajaran dengan model PBL maupun TPS merupakan pengetahuan awal mereka tentang materi Qur'an-Hadits yang diajarkan. Pengetahuan awal ini sangat dibutuhkan siswa pada saat

11 Nur, Muhammad dan Wikandari, Prima Retno, Pengajaran Berpusat Kepada Siswa dan Pendekatan Konstruktivitas dalam Pengajaran Edisi 5, (Semarang: Pusat Sains dan Matematika Sekolah Universitas Negeri Semarang, 2008), h. 57.

12 Warsono dan Hariyanto, Pembelajaran Aktif, (Jakarta: Remaja Rosdakarya, 2013), h. 152. 
penerapan model PBL mengingat pengetahuan awal tersebut dibutuhkan siswa dalam pengembangan pengetahuan mereka nantinya. Hal ini sejalan dengan pendapat Hong yang menjelaskan bahwa dalam sebuah proses pembelajaran yang menggunkan model PBL guru memberikan persoalan persoalan dari dunia nyata kepada para siswa untuk dicarari solusinya secara bersama-sama. ${ }^{13}$ Kemampuan siswa memecahkan masalah yang diberikan guru tergantung pada pengetahuan awal yang dimiliki siswa terkait materi pembelajaran. Proses pembelajaran berbasis masalah tersebut akhirnya menuntut siswa untuk aktif dalam kegiatan nyata seperti kegiatan observasi, pengumpulan data dan analisis secara bersama-sama dengan siswa lain dalam di kelompok ataupun di dalam kelas.

Kegiatan ini mendorong siswa setelah melalui proses pembelajaran berbasis masalah akan memiliki kemampuan berfikir yang lebih atas usaha atau proses pemecahan masalah yang mereka berikan sehingga mereka memiliki kepercayaan dalam diri untuk menuangkan gagasan serta pemahaman mereka melalui masalah yang diberikan guru. Hal ini didasari oleh pendapat Arends yang menjelaskan bahwa proses berpikir dalam kegiatan pembelajaran model PBL diperlukan untuk menuntaskan masalah yang dialami oleh siswa dalam proses pembelajaran yang berlangsung. Masalah yang ditampilkan pada siswa berbentuk konsep materi pembelajaran sehingga melalui permasalahan tersebut siswa diharapkan dapat terstimulus proses berpikirnya pada level yang lebih tinggi dalam memecahkan permasalahan. ${ }^{14}$ Kemampuan pemecahan masalah tersebut tentunya dipengaruhi oleh pengetahuan tentang materi pembelajaran yang diperoleh siswa melalui proses pembelajaran berbasis masalah yang diselenggarakan guru. Pengetahuan yang dapatkan siswa tersebut semata-mata bukan merupakan pemberian guru, tetapi juga berasal dari kemampuan siswa membentuk suatu ide, konsep, maupun pengetahuan. Tentunya peran guru menjadi cukup urgen dalam membentuk kemampuan siswa memunculkan ide, konsep maupun gagasan tersebut.

Hal ini diperkuat oleh Abuddin Nata yang menjelaskan bahwa PBL mendorong siswa mengembangkan kemampuan analisis dan sintesisnya terhadap suatu permasalahan yang selanjutnya mengupayakan suatu solusi atau jawaban terhadap permasalahan tersebut. ${ }^{15}$ Kemampuan analisis dan sintesis ini sesuai dengan paham konstruktivistik bukanlah gambaran dari dunia kenyataan yang ada, melainkan akibat dari suatu proses konstruksi kognitif kenyataan melalui kegiatan seseorang, seperti mengobservasi, mengumpulkan data maupun menganalisis data. Semua kegiatan-kegiatan tersebut akan diperoleh siswa melalui model PBL yang diselenggarakan guru sehingga akan terbentuk kemampuan kognitif dan

${ }^{13}$ Jon Chao, Hong, The Comparison of Problem Based Learning (PBL) Model and Project Based Learning (PBL) Model. (Internasional Conference on Engineering Education, 2007), h. 4.

${ }_{14}$ Richard Arends I, Classroom Instruction and Management, (USA: the Mc. Graw-Hill Companies, 1997), 156.

${ }^{15}$ Nata Abiddin, Persfektif Islam Tentang Strategi Pembelajaran, (Jakarta: Prenada Media,2009), 243. 
psikomotor siswa yang berupa skema, kategori, konsep dan struktur pengetahuan dalam rangka pemecahan masalah. Hal ini sejalan pula dengan pendapat yang diungkapkan oleh Warsono dan Hariyanto yang menyatakan bahwa pembelajaran kontekstual sebagai inti model PBL memungkinkan proses siswa menggunakan kecakapan dan kemampuan akademik dari berbagai konteks di kelas dan di luar kelas untuk memecahkan masalah dunia nyata secara perorangan dan berkelompok. ${ }^{16}$

Selain itu penjelasan Rusman juga memperkuat hasil penelitian ini bahwa model pembelajaran berbasis masalah menurut Rusman berusaha mendorong siswa untuk berpikir karena adanya proses yang mendorong peserta didik untuk mempertanyakan, kritis, reflektif. ${ }^{17}$ Lingkungan belajar dimana peserta didik hanya menerima informasi dari guru, menulis serta menghafalkannya harus diubah menjadi suatu bentuk sharing pengalaman dan pengetahuan, mencari (inkuiri), menemukan suatu pengetahuan secara aktif sehingga mampu mendukung terjadinya peningkatan pemahaman dan kemampuan berfikir peserta didik dalam proses pembelajaran.

Arends yang menjelaskan bahwa pembelajaran berbasis masalah dapat membantu siswa mengembangkan keterampilan berfikir, keterampilan menyelesaikan masalah dan keterampilan intelektualnya, mempelajari peran orang dewasa dengan mengalaminya melalui berbagai situasi riil atau yang disimulasikan serta menjadi pelajar yang mandiri. ${ }^{18}$ Selain itu Rusman juga menjelaskan bahwa pembelajaran berbasis masalah mendorong siswa untuk berpikir karena adanya proses yang membantu peserta didik untuk mempertanyakan, kritis, reflektif. ${ }^{19}$ Namun tentu saja peningkatan kemampuan siswa tersebut masih dalam skala yang paling rendah sehingga membutuhkan perlakuan yang berbeda jika mereka nanti berada di tingkat pendidikan yang lebih tinggi.

Satu hal yang juga menjadi catatan penting bahwa dalam penggunaan model PBL yang diterapkan guru dalam pembelajaran Qur'an Hadits kelas VII di MTs. Nurul Islam Sekarbela mengajarkan siswa belajar melalui suatu proses yang berkelanjutan dan bukan menekankan pada hasil yang diperoleh secara seketika. Melalui model PBL tersebut pengetahuan dan keterampilan siswa diperoleh sedikit demi sedikit, berangkat dari pengetahuan yang dimiliki sebelumnya. Konsep ini bersandar pada konsep belajar menurut teori psikologi asosiasi (koneksionisme) dimana belajar adalah suatu proses pembentukan asosiasi atau relevansi antara stimulus (perangsang) terhadap individu melalui penginderaan dan response (reaksi)

16 Warsono dan Hariyanto, Pembelajaran Aktif, (Jakarta: Remaja Rosdakarya, 2013), 152.

17 Rusman, Model-model Pembelajaran Mengembangkan Profesionalisme Guru, Jakarta: PT. Rajagrafindo Persada, 2010), 231.

18 Arends, I. Richard, Learning to Teach; Belajar untuk Mengajar. Terjemahan Helly Prajitno Soetjipto, (Jakarta: Pustaka Pelajar, 2008), h. 43-44.

${ }_{19}$ Rusman, Model-model, h. 232. 
yang dilakukan individu terhadap stimulus tadi dan proses penguatan hubungan tersebut. ${ }^{20}$ Berdasarkan pendapat tersebut maka kegiatan belajar akan dapat menghasilkan perubahan tingkah laku yang secara relatif tetap dalam berpikir, merasa dan melakukan pada peserta didik. Perubahan tingkah laku tersebut terjadi sebagai hasil latihan dan pengalaman terutama dalam menyikapi dan memberikan solusi atas suatu permasalahan.

Tentunya tolak ukur keberhasilan pelaksanaan pembelajaran dengan model Problem Based Learning (PBL) yang didasarkan pada pendekatan kontekstual, tergambar dari kemajuan belajar siswa yang diukur dari proses, kinerja dan produk (berupa solusi yang diberikan siswa), berbasis pada prinsip authentic assessment. Tentunya dalam hal ini guru dapat menyediakan pembelajaran dalam situasi yang nyata dengan objek yang nyata pula berupa permasalahan-permasalahan keseharian sehingga siswa mendapatkan pengetahuan yang bersifat permanen. Pembelajaran dengan model PBL ini tentunya akan memberi peluang pada sistem pembelajaran yang berpusat pada siswa, pembelajaran yang lebih kolaboratif sehingga siswa terlibat secara aktif memecahkan masalah yang diberikan baik secara mandiri maupun bekerja sama dengan kelompok.

Adanya pengaruh penggunaan model pembelajaran berbasis masalah terhadap peningkatan hasil belajar Qur'an-Hadits peserta didik di kelas VII memperlihatkan bahwa jika semakin optimal guru menggunakan model pembelajaran berbasis masalah di kelas dalam proses pembelajaran Qur'an Hadits maka hasil belajar peserta didik juga akan semakin optimal.

\section{SIMPULAN}

Berdasarkan hasil penelitian dan pembahasan maka diperoleh data bahwah hasil belajar pada saat posttest lebih tinggi dibanding saat pretest dan hasil uji hipotesis menunjukkan bahwa thitung sebesar 4,2 dengan signifikansi 0,003 dimana signifikansinya lebih kecil daripada 0,05 sehingga $\mathrm{H}_{\mathrm{o}}$ ditolak artinya ada perbedaan hasil belajar siswa yang signifikan siswa saat pretest dan posttest. Perbedaan tersebut menunjukkan adanya efektivitas penerapan model pembelajaran berbasis masalah terhadap peningkatan hasil belajar siswa. karena itu dapat disimpulkan bahwa model pembelajaran berbasis masalah efektif untuk meningkatkan hasil belajar karena model pembelajaran ini memiliki beberapa kelebihan, yaitu: a) Membuat peserta didik terbiasa menghadapi suatu permasalahan baik permasalahan tadi terjadi di dalam kelas taupun di luar kelas, b) menanamkan rasa kepedulian terhadap hubungan sosial yang terjalin dengan masyarakat di sekelilingnya, c) menjalin interaksi yang harmonis antara guru dengan peserta didik, serta d) melatih peserta didik untuk mampu mengimplementasikan metode eksperimen melalui sebuah proses pemecahan masalah.

${ }^{20}$ Syaiful Sagala, Konsep dan Makna Pembelajaran, (Bandung: Alfabeta,2013), h. 53. 


\section{DAFTAR PUSTAKA}

Abiddin, Nata. Persfektif Islam Tentang Strategi Pembelajaran, Jakarta: Prenada Media,2009.

Arends, I. Richard, Classroom Instruction and Management, USA: the Mc. Graw-Hill Companies, 1997.

Arends, I. Richard, Learning to Teach; Belajar untuk Mengajar. Terjemahan Helly Prajitno Soetjipto, Jakarta: Pustaka Pelajar, 2008.

Gulsah Kulekci - Esin Kumlu, "Developing Critical Thinking Skills In English Language Teaching Classes Through Novels". International Journal of Language Academy, Vol. 3 No. 2, Summer 2015.

Hadjar, Ibnu. Dasar-dasar Metodologi Penelitian Kwantitatif dalam Pendidikan, Jakarta: PT Raja Grafindo Persada, 2001.

Jon Chao, Hong, The Comparison of Problem Based Learning (PBL) Model and Project Based Learning (PBL) Model. Internasional Conference on Engineering Education, 2007.

Lestari, Ni Nyoman Sri. "Pengaruh Model Pembelajaran Berbasis Masalah (Problembased Learning) dan Motivasi Belajar terhadap Prestasi Belajar Fisika bagi Siswa Kelas VII SMP," Jurnal Teknologi Pembelajaran Indonesia 1, no. 2 (Oktober 2012), http:// ejournalpasca.undiksha.ac.id/index.php/jurnal_tp/article/view/297.

Mc. Millan, James H., Classroom Assessment, Principles \& Practice for Effective Standars-Based Instruction, Boston: Person Education Inc., 2007.

Mudlofir, Ali. Aplikasi Pengembangan Kurikulum Tingkat Satuan Pendidikan Dan Bahan Ajar Dalam Pendidikan Agama Islam, Jakarta: PT. Raja Grafindo Persada, 2012.

Nur, Muhammad, Muhammad dan Wikandari, dan Prima Retno, Pengajaran Berpusat Kepada Siswa dan Pendekatan Konstruktivitas dalam Pengajaran Edisi 5, Semarang: Pusat Sains dan Matematika Sekolah Universitas Negeri Semarang, 2008.

Permendikbud No. 69 Tahun 2013 Tentang Kerangka Dasar Dan Struktur Kurikulum Sekolah Menengah Atas/Madrasah Aliyah (Jakarta: Kemdikbud, 2013.

Reta, I. Ketut. "Pengaruh Model Pembelajaran Berbasis Masalah terhadap Keterampilan Berpikir Kritis Ditinjau dari Gaya Kognitif Siswa," Jurnal Pendidikan dan Pembelajaran IPA Indonesia 2, no. 1 (Januari 2012), http://ejournalpasca.undiksha.ac.id/index.php/jurnal_ipa/article/view/403.

Rusman, Model-model Pembelajaran Mengembangkan Profesionalisme Guru, Jakarta: PT. Rajagrafindo Persada, 2010.

Rusmono, Strategi Pembelajaran dengan Problem Based Learning Itu Perlu, Jakarta: Ghalia Indonesia, 2012.

Sagala, Syaiful. Konsep dan Makna Pembelajaran, Bandung: Alfabeta, 2013. 
Sugiono, Metode Penelitian Pendidikan Pendekatan Kuantitatif, Kualitatif, dan R\&D. Alfabeta: Bandung. 2001.

Syaifulloh, Ahmad. "Pengaruh Strategi Problem-Based Lear-Ning (PBL) terhadap Motivasi dan Hasil Belajar Peserta Didik pada Mata Pelajaran Fiqih di MA. Khozinatul 'Ulum Blora Jawa Tengah," Wahana Akademika: Jurnal Studi Islam dan Sosial 3, no. 2 (Desember 2016): 121-136, http://journal.walisongo.ac.id/index.php/wahana/article/view/1148.

Utomo, Tomi. Dwi Wahyuni, dan Slamet Hariyadi, "Pengaruh Model Pembelajaran Berbasis Masalah (Problem Based Learning) terhadap Pemahaman Konsep dan Kemampuan Berpikir Kreatif Siswa (Siswa Kelas VIII Semester Gasal SMPN 1 Sumbermalang Kabupaten Situbondo Tahun Ajaran 2012/2013)," Jurnal Edukasi 1, no. 1 (Maret 2014): 5-9, https://jurnal.unej.ac.id/index.php/JEUJ/article/view/1025.

Warsono dan Hariyanto, Pembelajaran Aktif, Jakarta: Remaja Rosdakarya, 2013. 